\title{
Evaluation of the efficiency of hybrid drive applications in urban transport system on the example of a medium size city
}

\author{
Marek Pawełczyk ${ }^{1, *}$, and Emilia Szumska ${ }^{2}$ \\ ${ }^{1}$ Faculty of Management and Computer Modelling, Kielce University of Technology, Al. Tysiąclecia P.P.7, 25-314, Kielce, Poland \\ ${ }^{2}$ Faculty of Mechatronics and Mechanical Engineering, Kielce University of Technology, Al. Tysiąclecia P.P.7, 25-314, Kielce, Poland
}

\begin{abstract}
Unconventional drive systems of the urban buses become more and more popular. The reason is clear: reduction of the harmful emissions as well as the fuel consumption reduction. Environmental aspects are becoming of the great importance. Local governments of large cities are "pushing" conventional buses away from city centres, trying to substitute them by the other more environmentally friendly urban vehicles. The goal of the contribution is to present a comparison of the selected types of the urban buses equipped with alternative drive systems under conditions of medium size city. The first part of the paper presents the methodology and construction of urban bus driving cycles prepared for Kielce city (Poland). The next part shows fuel economy and energy consumption obtained from simulation of urban buses powered by conventional diesel engine and hybrid electric drive under the developed driving cycles. The last part presents results of the Total Cost of Ownership (TCO) calculations estimated for selected urban buses.
\end{abstract}

\section{Introduction}

To evaluate the efficiency of the hybrid drive for urban public transport applications some most popular alternatives of the hybrid drives have been taken into account. The most attractive alternatives for the classical Diesel engine drive system are pure electric drives and hybrid drives. Pure electric autonomous vehicles are still very expensive although the price ratio of the conventional vehicles and electric vehicles has become more acceptable lately. Great progress has been taken place in the field of batteries offered, whose capacities and life time have increased significantly and the price has decreased. Recently, there has been a great deal of interest from the self-governments of the Polish cities manifesting itself in that they have already bought or are preparing to purchase a significant number of electric vehicles in Poland. More popular option is hybrid drive urban buses, which are offered in some different options by some Polish bus manufacturers. Among them the most typical are parallel and series hybrid vehicles, which have been chosen for the further consideration. Evaluation of the hybrid bud effectiveness has been conducted by use of the simulation model developed by the US National Renewable Energy Laboratory within the program "Partnership for a New Generation of Vehicles" (PNGV), co-financed by the US Department of Energy and the biggest American car manufacturers [4]. The model was developed in Matlab/Simulink simulation environment. The ADVISOR packages used to be able to download free of charge from the Program web site. The model can be used for alternative drive systems of the different types of the vehicles, including urban buses. To accommodate the model to local conditions of the medium-size city some driving cycles have been worked out.

\section{Driving cycles}

The driving cycle - Is a record of vehicle movement, represented as its speed vs. time. It does not provide detailed information about driving style, but illustrates the communication conditions of a given city and gives the basis for energy analysis of vehicle traffic $[1,2]$. The first driving cycle was developed in the 50s of the 20th century in Los Angeles to investigate the impact of emissions on the formation of smog. The cycle consisted of 11 modules, including the acceleration phase, driving at constant speed, braking and staging [3]. Standardized road cycles are currently used to estimate emissions of harmful emissions and fuel consumption.

In the EU, the NEDC cycle is now in use, in the USA the FTP-75 cycle is used, in Japan there are J10 or J15 cycles, in India - it is IDC cycle. Standardized On-Road Tests (SORT) have been developed to standardize mileage fuelling procedures for buses and public transport. They include three types of tests [4, 5]:

- SORT 1 (Heavy Urban), which reflects the operating conditions in the centre of large cities (average speed $12 \mathrm{~km} / \mathrm{h}$ );

- SORT 2 (Easy Urban Cycle), which reflects the operating conditions for a typical urban route (average speed is $18.0 \mathrm{~km} / \mathrm{h}$ );

- SORT 3 (Easy Suburban Cycle), which reflects traffic conditions in the suburbs of large cities and on inner routes of smaller cities (average speed is $25.3 \mathrm{~km} / \mathrm{h}$ ).

\footnotetext{
* Corresponding author: m.pawełczyk@tu.kielce.pl
} 
The complete cycle consists of a number of speed profiles that group basic cycles, with the following values: acceleration (decelerations), driving at constant speed, stopping time $[2,6,7]$. Standardized road cycles do not, however, reflect the actual communication conditions of a particular city. Therefore, in order to carry out an energy analysis of a particular vehicle and the emission of harmful exhaust particles, many researchers have undertaken to develop a driving cycle for specific cities [8-14]. This contribution presents the method of creating Kielce cycles of driving, which reflect the actual traffic conditions of urban communication vehicles in Kielce.

Two urban bus driving cycles have been worked out for the medium-size city (Kielce), the first one for a flat route (driving cycle I) and the second - for a route with a varied vertical profile (driving cycle II), both of them are based on the measurements conducted on the real bus routes in Kielce (Fig. 1).

Kielce driving cycle I reflects the route of line 13 that runs from the east to the west side of the city and has 39 bus stops. Its total length is $20.2 \mathrm{~km}$. The Kielce II cycle was built on the basis of line 30 , which runs from the north to the southern part of the city. There are 36 bus stops in the route and its length is $19.5 \mathrm{~km}$.

Kielce is characterized by uplifting terrain, with the absolute height of between 260 and $400 \mathrm{~m}$, therefore one of the route selection criteria was its vertical profile. Route 13 is characterized by a relatively flat vertical profile with a maximum slope of $1 \%$. Line 30 runs along the hilly route and the highest slope of the route is $4 \%$.

During the measurements of the Kielce cycles, the public transport bus of 12 meters in length. The vehicle was equipped with a Diesel engine of $209 \mathrm{~kW}$ (284 HP), its own weight was $10400 \mathrm{~kg}$, while the maximum allowable weight was $18000 \mathrm{~kg}$. Real-time traffic records were recorded using Kiestler GPS CDS Data Logger, installed by the authors on the vehicle. The data sent from the bus on-board GPS system to the ZTM
Kielce (bus provider) monitoring system was also taken into account.
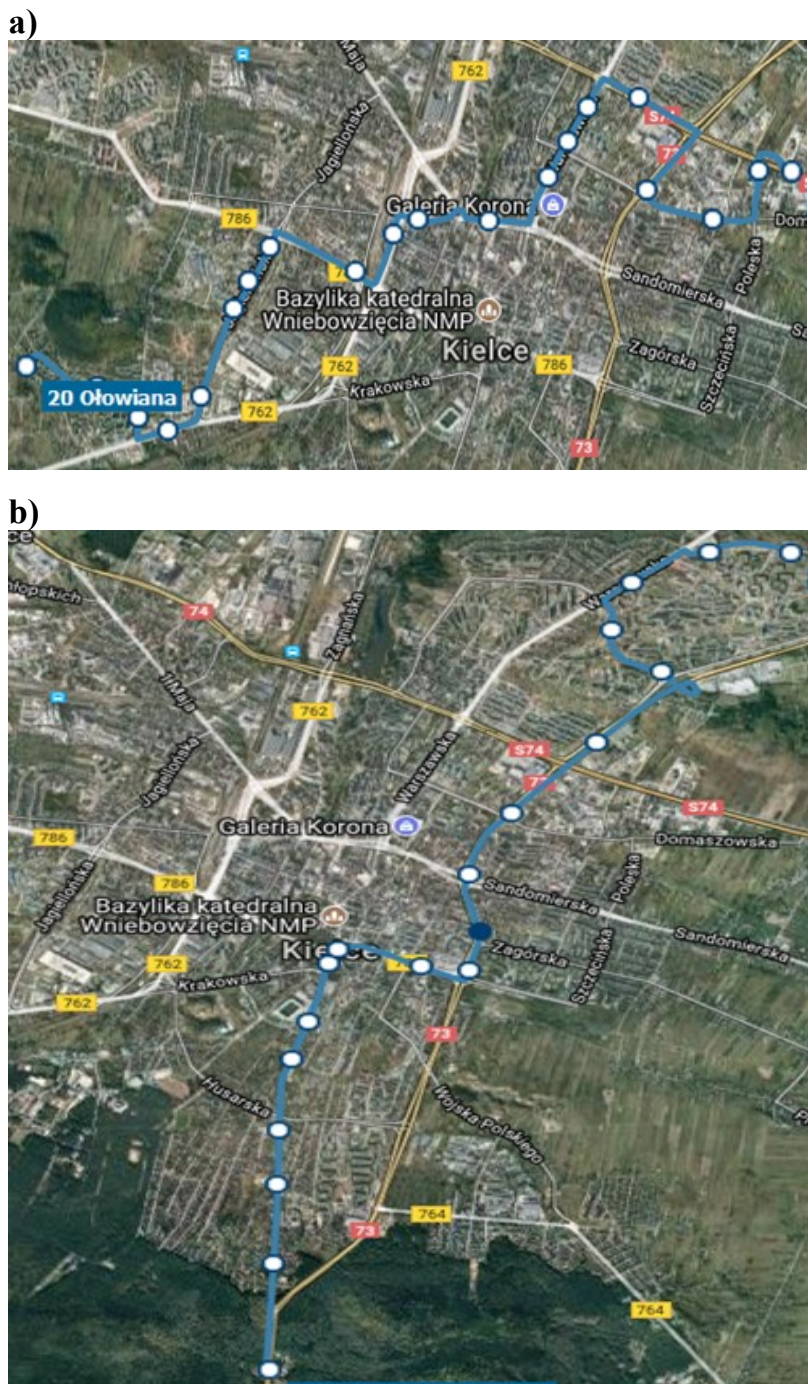

Fig. 1. Bus routes utilized for driving cycles construction: a) bus route No. 13 ; b) bus route No. 30 .
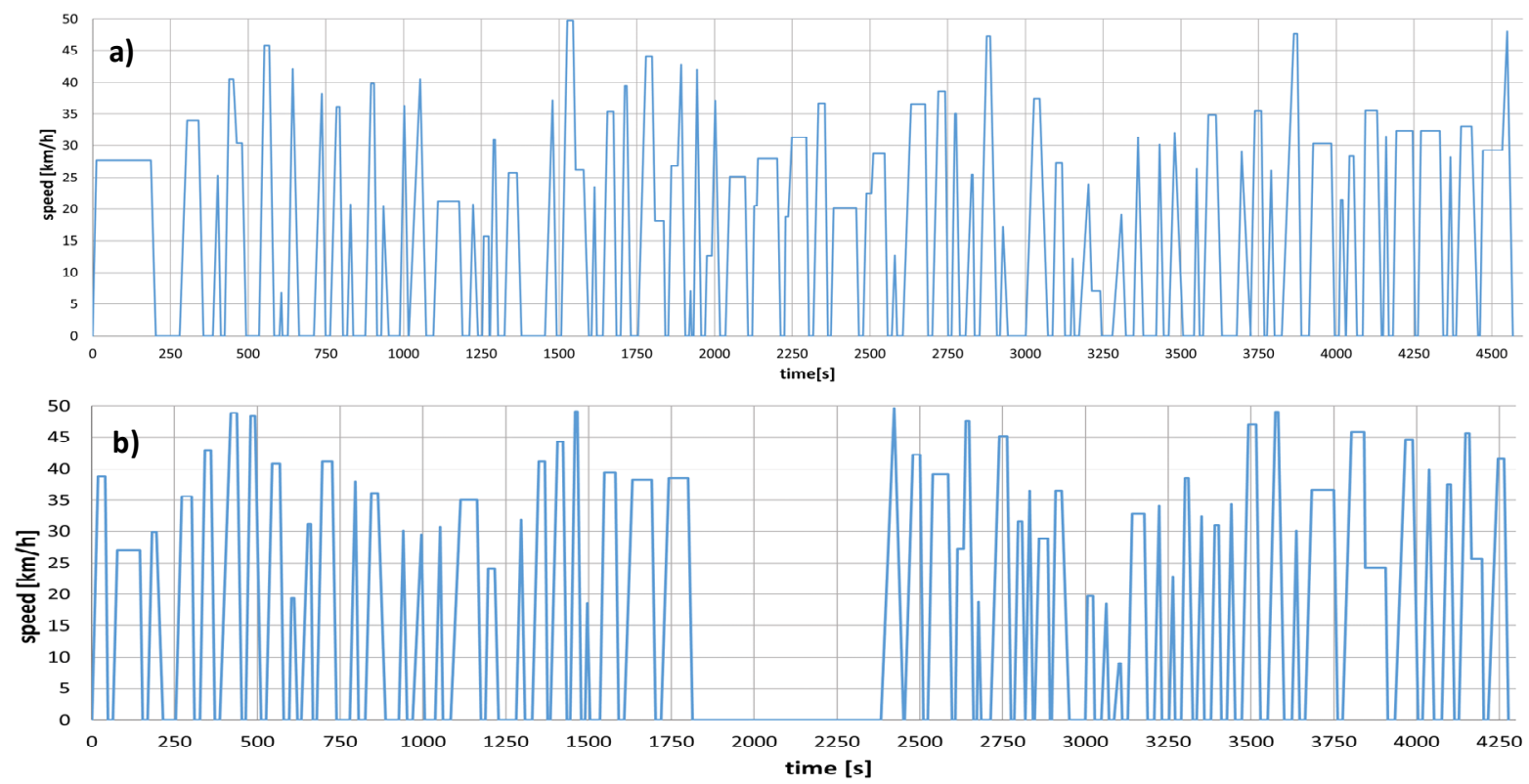

Fig. 2. Kielce driving cycle: a) driving cycle I; b) driving cycle II. 
When compiling the actual driving cycles, the following vehicle performance parameters were selected: instantaneous speed, instantaneous acceleration, driving time, distance travelled, and vehicle momentary. On the basis of the available data, journeys with similar stop counts and average speeds and similar cycles were identified. Then one of them was selected for each of the routes studied. These journeys were taken as actual driving cycles, recorded as instantaneous velocity distributions as a function of time (Fig. 2).

The actual driving cycles were divided into short runs between the following stops. For each of them the average speed, acceleration and deceleration were calculated. and delay. The mean value of the real cycle velocity is equal to the average speed of the representative cycle, and the mean acceleration of the actual cycle is equal to the average acceleration of the representative cycle.

Both routes run in urban areas, so the maximum speed should not be higher than $50 \mathrm{~km} / \mathrm{h}$. The representative Kielce driving cycle I lasts $4568 \mathrm{~s}$ and its length is $20,25 \mathrm{~km}$, its average speed is $15.95 \mathrm{~km} / \mathrm{h}$. This route is characterized by high variations in speed values and high variability of acceleration. The average acceleration is $0.55 \mathrm{~m} / \mathrm{s} 2$ and the average deceleration is $0.67 \mathrm{~m} / \mathrm{s} 2$. The total number of stops on the route was 66. The basic parameters of both cycles were presented in Table 1.

The driving cycle II is shorter by about $700 \mathrm{~m}$ and is characterized by a higher average speed $(16.44 \mathrm{~km} / \mathrm{h})$. Average acceleration is $0.54 \mathrm{~m} / \mathrm{s} 2$ and average deceleration is $0.81 \mathrm{~m} / \mathrm{s} 2$. The route is also characterized by a smaller proportion of congestion, which results in fewer stops. In the middle of the cycle, according to the actual timetable for this line, there a stop lasting $568 \mathrm{~s}$.

Most of the time of the two cycles were stops. For the driving cycle I it was $46 \%$, and for the driving cycle II it was $52 \%$ of the total cycle time. Since the both worked out representative cycles show the urban bus driving cycles, the total stoppage times included stopping times at stops and stopping times due to traffic conditions. For the driving cycle I, the percentage of times of the two types of stops differed only $2 \%$ whereas for the driving cycle II the differences were much higher - total stop time caused by traffic conditions was $38 \%$ higher than total bus stop time.

Table 1. Basic parameters of the driving cycles.

\begin{tabular}{|l|c|c|}
\hline \multicolumn{1}{|c|}{ Parameter } & $\begin{array}{c}\text { Driving } \\
\text { test I }\end{array}$ & $\begin{array}{c}\text { Driving } \\
\text { test II }\end{array}$ \\
\hline Test cycle time [s] & 4568 & 4276 \\
\hline Cycle length [km] & 20,25 & 19,53 \\
\hline Maximum speed [km/h] & 49,89 & 49,79 \\
\hline Average speed [km/h] & 15,95 & 16,44 \\
\hline Maximum acceleration [m/s $\left.\mathrm{s}^{2}\right]$ & 1,34 & 1,24 \\
\hline Maximum deceleration [m/s $\left.\mathrm{s}^{2}\right]$ & 1,49 & 1,66 \\
\hline Average acceleration $\left[\mathrm{s} / \mathrm{s}^{2}\right]$ & 0,55 & 0,54 \\
\hline Average deceleration $\left[\mathrm{m} / \mathrm{s}^{2}\right]$ & 0,67 & 0,81 \\
\hline Number of stops & 66 & 55 \\
\hline
\end{tabular}

\section{The urban bus variants}

Three types of vehicles have been chosen for simulations: the parallel hybrid bus, the series hybrid bus and the "classical" Diesel engine urban bus. The last one has been chosen to enable the comparison of the fuel consumption as the main parameter describing the bus usage efficiency.

Table 2. Technical parameters of the drive components of the analysed vehicles.

\begin{tabular}{|c|c|c|c|c|c|}
\hline & SHEV1 & SHEV2 & PHEV1 & PHEV2 & Conventional \\
\hline $\begin{array}{l}\text { Engine: } \\
\text { Maximum power: } \\
\text { Engine displacement: } \\
\text { Mass: }\end{array}$ & $\begin{array}{c}140 \mathrm{~kW} \\
7,3 \mathrm{dm}^{3} \\
476 \mathrm{~kg} \\
\end{array}$ & $\begin{array}{c}170 \mathrm{~kW} \\
7,3 \mathrm{dm}^{3} \\
476 \mathrm{~kg} \\
\end{array}$ & $\begin{array}{c}190 \mathrm{~kW} \\
6,7 \mathrm{dm}^{3} \\
404 \mathrm{~kg}^{2}\end{array}$ & $\begin{array}{c}200 \mathrm{~kW} \\
6,7 \mathrm{dm}^{3} \\
443 \mathrm{~kg} \\
\end{array}$ & $\begin{array}{c}205 \mathrm{~kW} \\
6,7 \mathrm{dm}^{3} \\
443 \mathrm{~kg} \\
\end{array}$ \\
\hline $\begin{array}{l}\text { Electric motor: } \\
\text { Power max: } \\
\text { Mass: } \\
\end{array}$ & $\begin{array}{c}150 \mathrm{~kW} \\
82 \mathrm{~kg} \\
\end{array}$ & $\begin{array}{c}180 \mathrm{~kW} \\
88 \mathrm{~kg}\end{array}$ & $\begin{array}{r}40 \mathrm{~kW} \\
48 \mathrm{~kg} \\
\end{array}$ & $\begin{array}{r}55 \mathrm{~kW} \\
66 \mathrm{~kg} \\
\end{array}$ & - \\
\hline $\begin{array}{l}\text { Generator: } \\
\text { Power max: } \\
\text { Mass: }\end{array}$ & $\begin{array}{c}150 \mathrm{~kW} \\
82 \mathrm{~kg}\end{array}$ & $\begin{array}{c}180 \mathrm{~kW} \\
88 \mathrm{~kg}\end{array}$ & - & - & - \\
\hline $\begin{array}{l}\text { Energy storage device: } \\
\text { Storage capacity: } \\
\text { Nominal voltage: } \\
\text { Mass: }\end{array}$ & $\begin{array}{l}9,4 \mathrm{kWh} \\
362 \mathrm{~V} \\
193 \mathrm{~kg}\end{array}$ & $\begin{array}{l}10,6 \mathrm{kWh} \\
362 \mathrm{~V} \\
231 \mathrm{~kg}\end{array}$ & $\begin{array}{l}5,6 \mathrm{kWh} \\
335 \mathrm{~V} \\
73 \mathrm{~kg}\end{array}$ & $\begin{array}{l}5,6 \mathrm{kWh} \\
335 \mathrm{~V} \\
73 \mathrm{~kg}\end{array}$ & - \\
\hline $\begin{array}{l}\text { Transmission: } \\
\text { Mass: }\end{array}$ & $\begin{array}{l}\text { BAE HDS200 } \\
31 \mathrm{~kg}\end{array}$ & $\begin{array}{c}\text { BAE HDS200 } \\
31 \mathrm{~kg}\end{array}$ & $\begin{array}{l}\text { ZF 5HP590 } \\
30 \mathrm{~kg}\end{array}$ & $\begin{array}{l}\text { ZF 5HP590 } \\
30 \mathrm{~kg}\end{array}$ & $\begin{array}{c}\text { ZF 5HP590 } \\
30 \mathrm{~kg}\end{array}$ \\
\hline $\begin{array}{l}\text { Gear ratio of the main } \\
\text { gear: }\end{array}$ & 5,857 & 5,857 & 4,33 & 4,33 & 4,33 \\
\hline
\end{tabular}




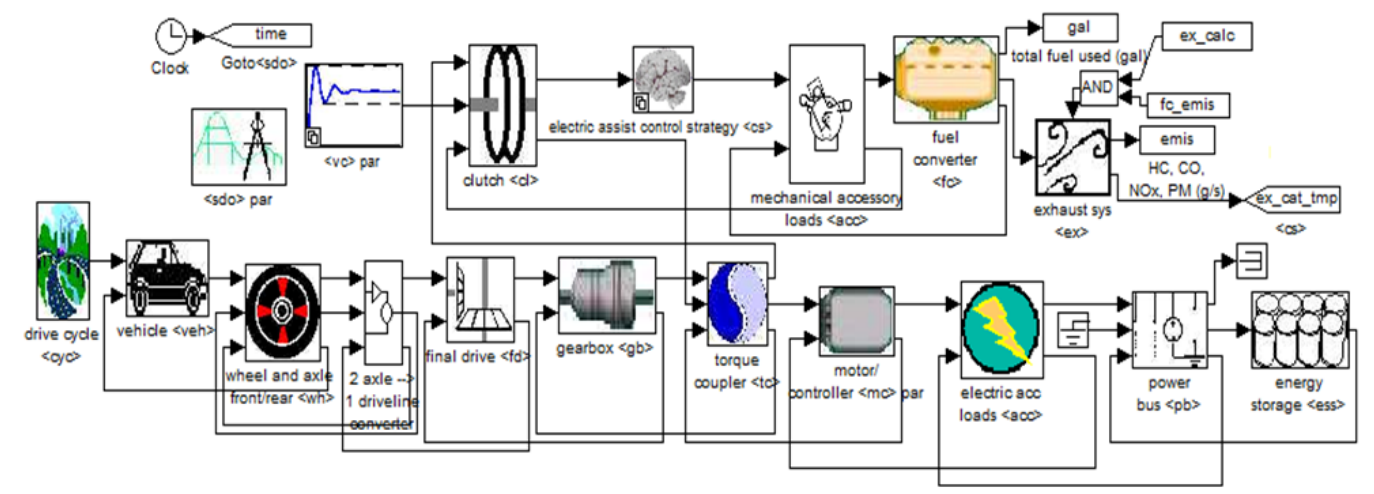

Fig. 3. Parallel hybrid vehicle simulation model - ADVISOR simulation environment.

\section{The simulation results}

The simulations have been conducted for two above mentioned driving cycles and three variants of the bus drive systems.

Simulation software, called ADVISOR, was implemented in Matlab/Simulink for simulating vehicles with different drive train configurations. As it was mentioned before it was developed by the American National Renewable Energy Laboratory (NREL). The program has built-in models of conventional, hybrid, parallel and electric vehicles. Fig. 3 presents a diagram of a vehicle model with a hybrid parallel drive. The program allows modifying the vehicle models by entering the vehicle data files, the characteristics and parameters of the drive components and the energy storage device. Different driving cycles can be chosen for the simulations and the user's driving cycle can be implemented [15-17].

The parameters of the vehicles chosen for the simulations were the Solaris $12 \mathrm{~m}$ bus parameters according to the producer data sheets. It was assumed that the maximum permissible total mass of each of the vehicles was 18 tons. The technical parameters of the drive components of the analysed vehicles have been shown in Table 2.

Authors have focused on the energy dependencies and fuel consumption issues. The simulation results presented below do not contain the tailpipe emissions, however in our opinion the emissions are proportional to the fuel consumption level.

The comparison of the two types of the hybrid buses shows that under conditions of the driving cycles taken into account the better fuel efficiency has been obtained for the parallel hybrid drive. The energy flow from the battery to the drive system and from the system to the battery (during regenerative braking) have been also studied.

Average fuel consumption for the driving cycle I has been shown on Fig. 4. The lowest average fuel consumption was recorded for vehicles equipped with a series hybrid system. These values were nearly $20 \%$ lower than for conventional vehicles. PHEV1 and SHEV2 hybrid vehicles have reported a $27 \%$ and $24 \%$ reduction in fuel consumption in comparison of a conventional drive vehicle. Average fuel consumption for the driving cycle II has been shown on Fig. 5.
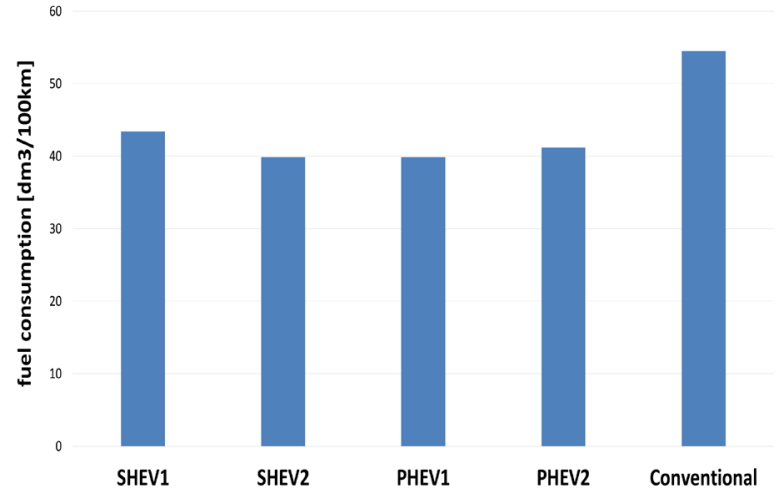

Fig. 4. Average fuel consumption for the driving cycle I $\left[\mathrm{dm}^{3} / 100 \mathrm{~km}\right]$.
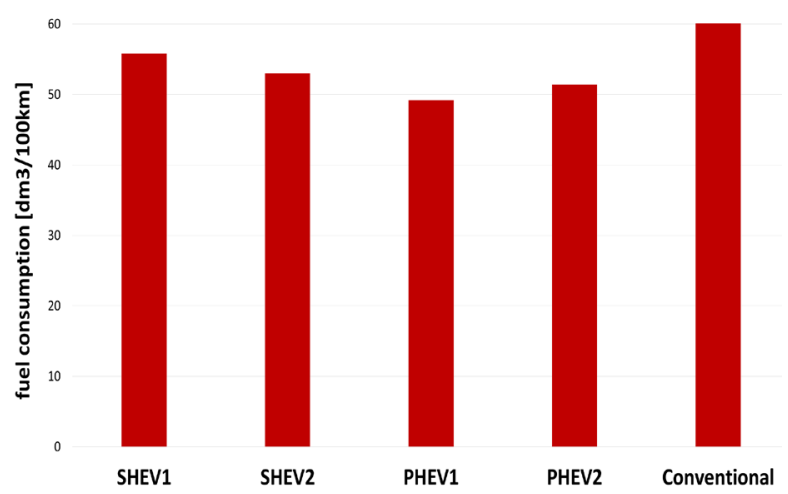

Fig. 5. Average fuel consumption for the driving cycle II $\left[\mathrm{dm}^{3} / 100 \mathrm{~km}\right]$.

Fig. 6 presents amounts of energy coming from the fuel combustion and returned from the storage tank in total amount of energy consumed in the cycle. The value of the energy required to complete the driving cycle I by the SHEV1 vehicle is $6 \%$, and by SHEV2 is $10 \%$ less than the energy consumed by the conventional vehicle. The energy returned from the energy storage device (ESD), consumed by the SHEV1 vehicle, is $15 \%$ of the total amount of the consumed energy. For the SHEV2 vehicle this ratio is $18 \%$. Vehicles with hybrid parallel drives needed $10 \%$ less energy than conventional vehicles. The ratio of ESD energy required to complete the cycle by the PHEV1 vehicle is $18 \%$ and $16 \%$ for the PHEV2 vehicle.

The lowest values of average fuel consumption were recorded for vehicles with parallel hybrid drive. During the driving cycle II PHEV1 recorded $11 \%$ and PHEV2 $7 \%$ consumed less energy than a classic-powered 
vehicle. We should add that these amounts of energy were calculated for one driving cycle only, so to evaluate the real energy effectiveness SOC level for ESD must be taken into account.

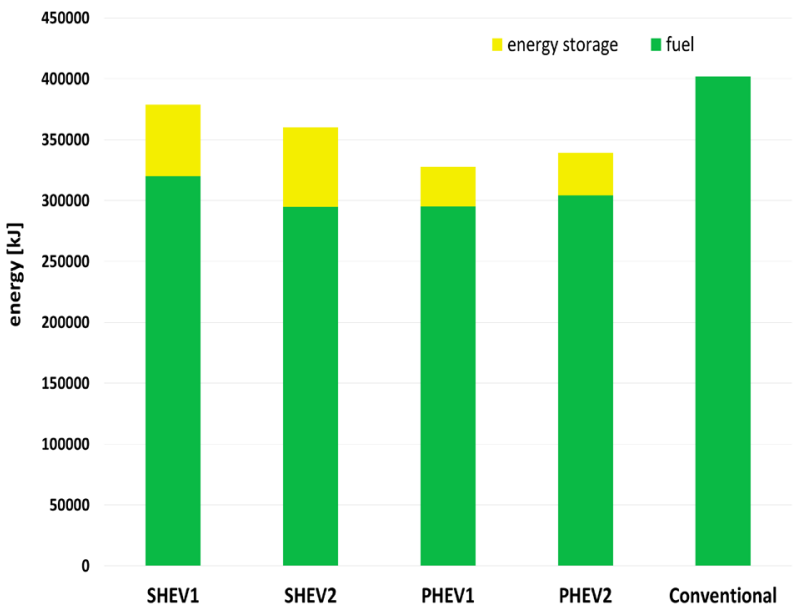

Fig. 6. Amounts of energy $[\mathrm{kJ}]$ coming from the fuel combustion (green) and returned from the storage tank (yellow) in total amount of energy consumed in the cycle I.

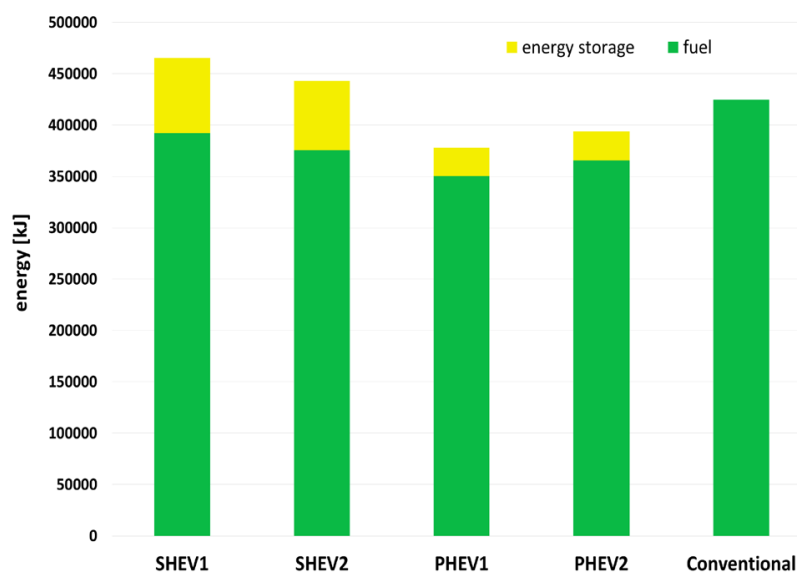

Fig. 7. The amounts of energy $[\mathrm{kJ}]$ from the fuel (green) and from the ESD (yellow) in total energy amounts consumed in both driving cycle II.

Our investigations show that hybrid vehicles require about $11 \%$ less energy than conventional vehicles. The estimated share of energy from batteries for parallel hybrid vehicles was 7\%. For SHEV1 and SHEV2 these ratios were $16 \%$ and $15 \%$ respectively. The amount of energy from the fuel and from the ESD in total energy consumed in second driving cycle can be seen on Fig. 7.

For both driving cycles we have stated that the lowest energy values were observed for vehicles with parallel hybrid drive. For the driving cycle II, vehicles with series hybrid powertrain needed 19\% more energy than for the driving cycle II. In the case of parallel hybrid vehicles, PHEV1 needed 13\% and PHEV2 14\% more energy for the driving cycle II than for driving cycle I. The share of the energy returned from the storage tank was higher for the driving cycle II. The biggest differences were observed for SHEV2.

\section{The TCO (Total Cost of Ownership) evaluation}

The TCO has been used for a vehicle total cost of ownership estimation the for a specific period of time. It includes all the expenses spent on fuel, insurance, maintenance, repairs, service, interest on loan payments as well as the losses incurred due to depreciation of the car at the end of the same period [18-23].

The life cycle costs, calculated for the three types of buses mentioned, including fuel costs, service costs, the battery exchange costs, show that the hybrid drive buses can be the cost effective alternative for a classical bus, even having taken into account the actual hybrid drives and batteries prices.

Total Cost of Ownership (TCO) is the sum of all costs of a vehicle, from its purchase, through use, to disposal. TCO analysis allows to evaluate the direct and indirect costs associated with vehicle usage and possession. In addition to the purchase cost, the total costs of living are included (fuel and/or energy costs, insurance, maintenance and repair costs).

The total cost of ownership can be written as follows:

$$
K_{T C O}=K_{Z}+N_{P} \cdot\left(K_{f}+K_{u}\right)+N_{W} \cdot K_{A}
$$

where $K_{T C O}$ - total vehicle cost $[\mathrm{PLN}], K_{Z}-$ vehicle purchase cost [PLN], $N_{P}$ - vehicle operating period, $K_{f}-$ cost of fuel [PLN/year], $K_{u}-$ cost of maintenance [PLN/year], $N_{W}$ - number of battery exchanges during the life of the vehicle, $K_{A}$ - purchase cost of the battery [PLN].

Calculating TCO for a vehicle equipped with a hybrid drive some additional costs connected with the battery exchange must be taken into account. The vehicle life time is as a rule longer than the battery usage time, so the battery must be exchanged a few times. A very important factor, determining the cost of the purchase of a new vehicle, the battery exchange cost as well as the energetic effectiveness of the bus is a battery capacity.

Three city buses with a length of 12 meters were selected for the analysis. The annual mileage for each selected bus is $70200 \mathrm{~km}$. The life time of each bus is 18 years. The first one has a conventional combustion engine, which complies with the European Euro 6 emission standard. According to the producer data it has been assumed that the average fuel consumption of this vehicle is $43.3 \mathrm{dm}^{3} / 100 \mathrm{~km}$. The second vehicle is the Solaris Urbino 12, equipped with a hybrid Eaton hybrid drive. The bus has a lithium-ion battery with a capacity of $3.6 \mathrm{kWh}$. Average fuel consumption is $33.7 \mathrm{dm}^{3} / 100$ $\mathrm{km}$. The third vehicle is the next-generation Solaris Urbino 12 Hybrid (launched in 2016), equipped with a hybrid BAE HybriDrive. According to the bus manufacturer data, average fuel consumption is 27 $\mathrm{dm}^{3} / 100 \mathrm{~km}$. The bus has a lithium-ion (LFP type) 
battery with a capacity of $11.6 \mathrm{kWh}$. It was assumed that the battery life time is 6 years. Therefore, the battery pack replacement is required two times during vehicle lifetime. The cost of lithium-ion battery is 900 PLN per kilowatt-hour. The following purchase prices were assumed: the conventional vehicle - 950,000 PLN, the parallel hybrid - PLN 1,200,000 PLN, the series hybrid - 1,300,000 PLN. According to [24] the average maintenance cost assumed for conventional bus - is 35000 PLN per year, for hybrid buses - 48000 PLN per year. The fuel price is $4.4 \mathrm{PLN}$ per $\mathrm{dm}^{3}$. It should be noted that the TCO analysis was carried out for current prices of fuel and lithium-ion battery per $\mathrm{kWh}$. These prices are variable and it is difficult to predict their level in the future. It should also be noted that the changes of money value over time has not been taken into account in these calculations.

The conducted analysis has shown that the total cost of ownership of a conventional bus, referenced to $1 \mathrm{~km}$, is PLN 3.12. The TCO of the parallel hybrid bus is 3.09 $\mathrm{PLN} / \mathrm{km}$, and the TCO for the series hybrid drive system is $7 \%$ lower - it has been estimated as $2.89 \mathrm{PLN} / \mathrm{km}$. As it has been mentioned before the TCO has been calculated as the sum of fuel costs, maintenance costs and battery replacement costs. Hybrid buses have lower operating costs (TCO) than conventional vehicles. These differences are respectively about $10 \%$ for parallel hybrids and $22 \%$ for serial hybrids.

The costs of fuel accounts for the largest share of total vehicle ownership. In the case of TCO of a conventional drive vehicle, their share is $61 \%$. For hybrid vehicles, the cost of fuel is lower - it is $48 \%$ for parallel hybrids and $41 \%$ for serial hybrids.

The share of the purchase cost in TCO of hybrid buses is more than $30 \%$. They have a much higher production costs. Additional costs stem mainly from the use of electric drive components such as batteries, electric motors and electronic components for energy management and thermal balance. Electric auxiliaries improve energy efficiency, but since the market for these items is still small, their costs are quite high.

\section{Conclusions}

The results of investigations, presented in the paper, show, that hybrid buses are becoming an attractive alternative for urban public transport, especially in medium size cities. However, presented results have not taken into account the environmental aspects of the vehicles' operation. Hybrid buses offer better energy efficiency and fuel efficiency in comparison with conventional buses. They have also a significantly lower Total Cost of Ownership (TCO) then buses equipped with conventional drive.

The trends of reducing air pollution caused by exhaust gases emitted by the urban buses and the tendency to add to TCO some additional costs connected with the environmental effects will have a positive effect on evaluating the effectiveness of the utilizing hybrid drive technology. The authors have shown, that even taking to account only TCO proves a profitability of implementation hybrid buses in cities.

The purchase cost of buses equipped in hybrid drive is still much higher than for the conventional bus. It is possible that the difference in the purchase costs between hybrid and conventional buses will decrease in the future. The advantages of hybrids is that they do not require additional and expensive infrastructure and bring additional environmental and social benefits.

\section{References}

1. J. Peng, D. Pan, H. He, Study on the driving cycle construction for city hybrid bus, Procedeengs of International Conference on Intelligent Systems Research and Mechatronics Engineering (ISRME 2015), China, 1-9 (2015).

2. U. Galgamuwa, L. Perera, S. Bandara, Developing a general methodology for driving cycle construction: comparison of various established driving cycles in the world to propose a general approach, Journal of Transportation Technologies, 5, 191-203 (2015)

3. T.J. Loyson, J.R. Konworthy, P.I. Austin, P.W.G. Newman, The development of driving cycle for fuel consumption and emissions evaluation, Transportation Research, 20 (6), 447-462 (1986)

4. UITP 2004, SORT - Standardized On-Road Test Cycles. UITP - International Association of Public Transport (2004)

5. UITP 2009, SORT - Standardized On-Road Test Cycles. UITP - International Association of Public Transport (2009)

6. Z. Dai, D. Niemeier, D. Eisinger, Driving cycle: A new cycle-building method that better represents real-world emissions, U.C. Davis-Caltrans Air Quality Project, Department of Civil and Environmental Engineering, University of California, Davis (2008)

7. J. Peng, D. Pan, H. He, Study on the driving cycle construction for city hybrid bus, Procedeengs of International Conference on Intelligent Systems Research and Mechatronics Engineering (ISRME 2015), China, 1-5 (2015)

8. E. Szumska, D. Zielińska, M. Pawełczyk, Konstrukcja cykli jazdy komunikacji miejskiej w Kielcach (Construction of the Kielce Driving Cycles), Autobusy - Technika, Eksploatacja, Systemy Transportowe, 17, 1372-1376 (2016)

9. P. Chauhan Boski, G. Joshi, P. Purnima, Vehicular speed pattern analysis on access controlled urban roadway in Surat City, Technical Research Organization India, 2, 137-143 (2015)

10. E. Tzirakis, F. Zannikos, Urban Driving Cycles for Greece, Procedeengs of 19th International Transport and Air Pollution Conference (TAP 2012), Greece, 1-6 (2012)

11. J. Zhu, Q. Shi, J. Zhou, The city bus driving cycle construction, Procedeengs of Second International 
Conference on Mechanic Automation and Control Engineering (MACE), Chiny, 2687-2690 (2011)

12. D. Covaciu, I. Preda, D. Florea, J. Timar, O. Câmpian, Analysis of a driving cycle proposed for Brasov City, Proceedings of International Automotive Congress (CONAT 2010), Romania, 1-8 (2010)

13. X. Gao, B. Zhang, X. Xiong, M. Dong, H. Li, Construction and analysis of the Dalian Driving Cycle, International Journal of Control and Automation, 8 (6), 363-368 (2015)

14. S.H. Kamble, T. Mathew, G. Sharma, Development of real-world driving cycle: Case study of Pune, India, Transportation Research Part D: Transport and Environment , 14 (2),. 132-140 (2009)

15. T. Markel, A. Brooker, T. Hendricks, V. Johnson, K. Kelly, B. Kramer, M. O'Keefe, S. Sprik, K. Wipke, ADVISOR: a systems analysis tool for advanced vehicle modeling, Journal of Power Sources, 110, 255-266(2002)

16. D. Chen, X. Li, L. Chen, L. Yang, F. Tian, D. Xu, Research on simulation of the hybrid electric vehicle based on software ADVISOR, Sensors \& Transducers, 171, 68-77 (2014)

17. http://adv-vehicle-sim.sourceforge.net

18. E. Szumska, M. Pawełczyk 2017, Porównanie TCO autobusów miejskich $z$ hybrydowym $i$ konwencjonalnym uktadem napędowym (TCO comparison of the urban conventional and hybrid buses), Zeszyty Naukowe Politechniki Warszawskiej, Seria Transport, z. 118, 277-285 (2017)

19. Review of the Research Program of the Partnership for a New Generation of Vehicles: Seventh Report. Transportation Research Board Washington, https://doi.org/10.17226/10180

20. B.M. Al-Alawi, T.H. Bradley, Total cost of ownership, payback, and consumer preference modeling of plug-in hybrid electric vehicles, Applied Energy 103, 488-506 (2013)

21. L. Nurhadi, S. Boren, H. Ny, A sensitivity of total ownership for electric public bus transport systems in Swedish medium sized cities, Transportation Research Procedia 2, 818-827 (2014)

22. B. Propfe, M. Redelbach, Cost analysis of plug-in hybrid electric vehicles including maintenance \& repair costs and resale values, Procedeengs of International Battery, Hybrid and Fuel Cell Electric Vehicle Symposium EVS26, USA, 1-10 (2012)

23. G. Wu, A. Inderbitzin, C. Bening, Total cost of ownership of electric vehicles compared to conventional vehicles: A probabilistic analysis and projection across market segments, Energy Policy 80, 196-214 (2015)

24. Panorama et évaluation des différentes filières d'autobus urbains 2015, ADEME - French Environment and Energy Management Agency, http://www.ademe.fr 